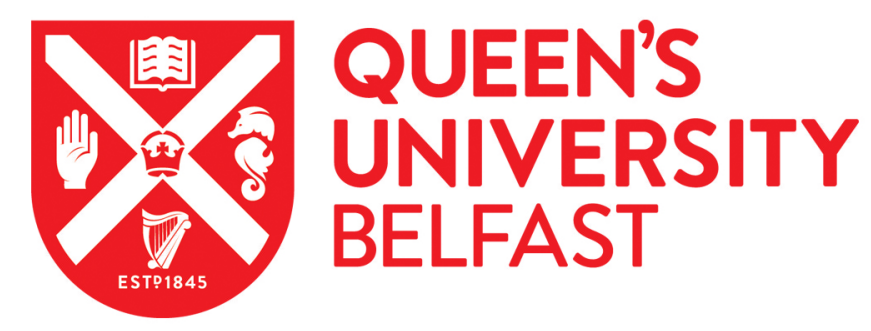

\title{
Essentialist beliefs affect children's outgroup empathy, attitudes and prosocial behaviours in a setting of intergroup conflict
}

O'Driscoll, D., Taylor, L., \& Dautel, J. (2021). Essentialist beliefs affect children's outgroup empathy, attitudes and prosocial behaviours in a setting of intergroup conflict. INTERNATIONAL JOURNAL OF PSYCHOLOGY, 56(1), 151-156. https://doi.org/10.1002/ijop.12679

Published in:

INTERNATIONAL JOURNAL OF PSYCHOLOGY

Document Version:

Peer reviewed version

Queen's University Belfast - Research Portal:

Link to publication record in Queen's University Belfast Research Portal

Publisher rights

Copyright 2020 Taylor and Francis. This work is made available online in accordance with the publisher's policies. Please refer to any applicable terms of use of the publisher.

\section{General rights}

Copyright for the publications made accessible via the Queen's University Belfast Research Portal is retained by the author(s) and / or other copyright owners and it is a condition of accessing these publications that users recognise and abide by the legal requirements associated with these rights.

Take down policy

The Research Portal is Queen's institutional repository that provides access to Queen's research output. Every effort has been made to ensure that content in the Research Portal does not infringe any person's rights, or applicable UK laws. If you discover content in the Research Portal that you believe breaches copyright or violates any law, please contact openaccess@qub.ac.uk. 
Running header: ESSENTIALISM AND INTERGROUP RELATIONS

International Journal of Psychology, in press

\title{
Essentialist beliefs affect children's outgroup empathy, attitudes and prosocial behaviours in a setting of intergroup conflict
}

\author{
Dean O’Driscoll ${ }^{1}$, Laura K. Taylor ${ }^{2,1}, \&$ Jocelyn B. Dautel $^{1}$ \\ ${ }^{1}$ Queen's University Belfast \\ ${ }^{2}$ University College Dublin
}

The study was supported financially by the School of Psychology Research Incentivisation Scheme and Summer Student Scheme as well as through the countless hours of data collection by our undergraduate and Master's student research team in the Helping Kids! lab (http://helpingkidsqubblog.com). Finally, we would like to extend our deep appreciation to the numerous school administrators, teachers, parents, and pupils for participating in these studies.

Correspondence concerning this article should be addressed to Dean O'Driscoll, Doctorate in Educational, Child, and Adolescent Psychology, School of Psychology, 18 - 30 Malone Road, Belfast BT9 5BN, Northern Ireland. E-mail: dodriscoll02@qub.ac.uk 


\title{
ESSENTIALISM AND INTERGROUP RELATIONS
}

\begin{abstract}
Empathy for salient outgroups can promote positive intergroup attitudes and prosocial behaviours. Less is known about which factors may promote empathy, particularly among children, in contexts of intergroup conflict. Empathy may depend on underlying cognitions, such as social essentialist beliefs, that is, believing that certain social categories have an underlying essence that causes members to share observable and non-observable properties. This study explored the influence of essentialist beliefs about ethno-religious categories on outgroup-directed empathy, attitudes, and prosocial behaviours of children living in Northern Ireland (N=88; $M=7.09, S D=1.47$ years old). Bootstrapped chain mediation found that lower essentialist beliefs predicted greater outgroup-directed empathy, which was positively related to outgroup attitudes, which in turn, predicted more outgroup prosocial behaviours. The findings highlight the importance of essentialist beliefs as an underlying factor promoting empathy, with links to prosocial behaviours in settings of intergroup conflict. The intervention implications are discussed.
\end{abstract}

Keywords: children, essentialist beliefs, empathy, intergroup conflict, outgroup prosocial behaviours 
ESSENTIALISM AND INTERGROUP RELATIONS

\section{Essentialist beliefs affect children's outgroup empathy, attitudes and prosocial behaviours in a setting of intergroup conflict}

Persistent intergroup divisions in post-accord societies have an impact on those born after the height of violence (Reidy et al., 2015). Children growing up in post-accord generations are often socialised by a legacy of the conflict (Taylor, Štambuk, Čorkalo Biruški, \& O'Driscoll, 2020b), and may think about outgroup members as distinct 'kinds' or people with within-group similarities and between-group differences (Dautel, 2012). Research in these settings has tended to focus on the role of young people in maintaining intergroup hostilities. Less is known about factors that inhibit or promote positive youth outcomes, such as prosocial behaviour (Taylor et al., 2014), which may be an antecedent for peacebuilding when directed toward outgroup members (Taylor \& McKeown, 2017).

Examining the underlying cognitive and social psychological mechanisms that contribute to positive intergroup attitudes and behaviours may have advantages in conflict settings. Children's attitudes may influence engagement in intergroup behaviours associated with peacebuilding (O’Driscoll, Taylor, \& Dautel, 2018). Similarly, empathy may counteract budding intergroup divisions. For example, testing the empathy-attitudes-action model, higher levels of empathy related to more positive outgroup attitudes, which in turn, promoted more prosocial behaviours across group lines among children and adolescents living amid intergroup conflict (Taylor, O’Driscoll, Dautel, \& McKeown, 2020a). That is, experiencing empathy for members of the opposing group may sensitise children to their well-being, which may generalise to more positive attitudes toward the outgroup as a whole and motivate a desire to help (Taylor et al., 2020a). A number of factors can promote or diminish outgroupdirected empathy, such as positive intergroup encounters (Turner, Tam, Hewstone, Kenworthy, \& Cairns, 2013). However, given the entrenched and polarised nature of post- 
accord settings, these opportunities are often limited. Research in these contexts must look at children's understanding of salient social categories, as group membership tends to remain a key social dimension that influences day-to-day interactions (Reidy et al., 2015). There is a need, therefore, to explore factors underlying how social categorization influences empathy, and subsequently prosocial behaviour within conflict settings.

Social categorization may influence children's intergroup experiences of empathy. For example, children tend to feel more empathy for members of their own group over other groups (Masten, Gillen-O’Neel, \& Brown, 2010). Thinking about an outgroup member as a distinct 'kind' of person different from oneself, may limit the ability to share his/her feelings. Children in divided societies also are more likely to hold essentialist beliefs about salient groups, which may emerge across early and middle childhood (Dautel, 2012; Smyth, Feeney, Eidson, \& Coley, 2017). Such social essentialist reasoning is the intuitive, and often implicit, assumption that people who belong to the same social category share an underlying, powerful essence that causes group members to share observable and non-observable traits and behaviours (Gelman, 2003). Children assume such shared properties to be biologically inherited and stable across time.

Intergroup conflict may accentuate children's essentialist thinking around social groups and promote intergroup biases. For example, heightening the salience of essentialist beliefs about ethnicity in the Israeli-Palestinian conflict led 6-year-old Jewish Israeli children to draw members of the two groups further apart and depict the ingroup in a more positive light (Diesendruck \& Menahem, 2015). Essentialism may also influence outgroup prosocial behaviour. That is, inducing essentialist beliefs around minimal groups related to children sharing fewer resources with outgroup members, but not more negative outgroup attitudes (Rhodes, Leslie, Saunders, Dunham, \& Cimpian, 2017). By assuming objective boundaries and fewer shared properties between "us" and "them," essentialist beliefs may also produce 
biases in empathy for outgroup members, subsequently affecting positive intergroup outcomes.

The current paper extends previous work by exploring the role of essentialist beliefs about ethno-religious categories on the outgroup-directed empathy, attitudes, and prosocial behaviours of children in post-accord Northern Ireland. Conflict between the Protestant and Catholic communities in Northern Ireland goes back centuries and represents distinct ethnic, political, and religious elements. The most recent period of sectarian violence, known as 'The Troubles' (1968 to 1998), officially ended with the signing of the Good Friday/Belfast Peace Agreement. However, the region continues to be divided along Protestant-Catholic lines, which shapes the social environment of the post-accord generation. For example, a majority of children live in segregated neighbourhoods and attend separate schools. The identities of Protestant and Catholic remain highly salient and some children essentialise these ethnoreligious categories (Smyth et al., 2017). Given the potential impact of essentialism on children's social cognitions, it is hypothesised that holding lower essentialist beliefs about ethno-religious categories may be linked with higher empathy for outgroup members, and in turn, more positive outgroup attitudes and prosocial behaviours across group lines.

\section{Method}

\section{Participants}

Children were recruited from three primary schools in Belfast (two state controlled de facto Protestant schools and one Catholic-maintained school) in spring 2016. The sample comprised of 88 children, aged 5 to 9 years old $(M=7.09, S D=1.47 ; 48 \%$ female; $50 \%$ Protestant; 50\% Catholic). Participating schools were segregated by ethno-religious background, with a majority (>70\%) of children attending being either Protestant or Catholic. Schools served economically disadvantaged neighbourhoods with over $70 \%$ of pupils entitled to receive free school meals. 


\section{ESSENTIALISM AND INTERGROUP RELATIONS}

\section{Procedure}

Consent was obtained from school principals, parents, and children before taking part in the study. Children were individually tested by a trained experimenter in a quiet area of their school. Children initially completed training measures before moving on to the primary tasks relating to the study. The session lasted approximately 15 minutes.

\section{Measures}

Essentialist beliefs. Children's essentialist beliefs about ethno-religious categories of Protestant and Catholic were assessed using the essentialism components questionnaire (Diesendruck \& Haber, 2009). The scale consisted of two subscales which assessed the children's beliefs around distinctiveness (i.e., differing physical and psychological traits between category members) and stability (i.e., inflexible to change) of these social groups.

On the distinctiveness subscale, children reported on six items about their beliefs that the two communities differed in preferences, appearance, behaviour, biological makeup, and cognitions on a 5-point scale using illustrations of balloons from $0=$ not at all (small balloon) to $4=$ completely (large balloon). On the stability subscale, children reported on three items around whether it was possible to change membership from one community to the other on a 3-point traffic light scale from $0=$ possible (green light) to $2=$ impossible (red light). Responses for each item on the subscales were converted to z-scores and summed to give a total for children's essentialist beliefs about ethno-religious categories (see Diesendruck \& Weiss, 2015). Higher scores indicated higher essentialist beliefs.

Outgroup-directed empathy. Outgroup-directed empathy was assessed using a measure adapted for use with children in Northern Ireland (Turner et al., 2013). The measure consisted of four items. Children reported feelings of empathy for members of the other community across different scenarios (e.g., children not sharing toys with an outgroup member) using a 4-point smiley-face scale ranging from $0=$ not happy or sad (neutral face) 
to 3 = very awful (the saddest face). Higher scores indicated greater empathy for outgroup members.

Outgroup attitudes. Outgroup attitudes were assessed using a measure adapted from research examining the effect of empathy on children's intergroup attitudes (Nesdale, Milliner, Duffy, \& Griffiths, 2009). The scale mapped the original measure with only the target outgroup changed to reflect the context of Northern Ireland. Children reported on three items about how much they liked, trusted, and would like to play with members of the other community. Children responded to each item on a 4-point scale represented using illustrations of animals that differed in size and affect from $0=I$ don't like them at all (large animal with a frown) to $3=$ I like them a lot (large animal with a smile). Higher scores reflected more positive outgroup attitudes.

Outgroup prosocial behaviour. Children were tasked to share seven stickers with two sex-matched children sick in hospital, one Protestant and one Catholic (O'Driscoll et al., 2018). The total number of stickers allocated to each child provided a score for ingroup and outgroup giving. Scores ranged from 0 to 7 . Only outgroup giving scores were included in the analysis. Higher scores indicted more outgroup prosocial behaviour.

\section{Results}

The means, standard deviations, internal consistencies and bivariate correlations for study variables are presented in Table 1. Chain mediation analysis was tested in SPSS using Model 6 of the PROCESS tool. The mediation examined the effect of essentialist beliefs about ethno-religious categories on outgroup prosocial behaviour via children's outgroupdirected empathy and attitudes (Figure 1). The mediation was bootstrapped with 5,000 replications. Unstandardized regression coefficients were reported. The sample size was sufficient to detect a medium effect at standard power and significance levels (Cohen, 1992) 
The overall model explained $18 \%$ of the variance in children's outgroup prosocial behaviour, when controlling for age, sex, and community background; only age was significant and negatively predicted outgroup attitudes $(\mathrm{b}=-.48$, se $=.21, p<.05)$. In relation to the mediation paths, lower essentialist beliefs about ethno-religious categories predicted greater outgroup-directed empathy $(b=-.18$, se $=.06, p<.01)$, which related to more positive outgroup attitudes $(\mathrm{b}=.32$, se $=.12, p<.05)$. More positive outgroup attitudes, in turn, predicted sharing more stickers with an outgroup member $(\mathrm{b}=.18$. se $=.06, p<.01)$. The indirect effect of children's essentialist beliefs on outgroup prosocial behaviour was significant $(\mathrm{b}=-.01$, se $=.01 ; 95 \%$ CI: $-.029,-.001)$. The direct effect of essentialist thinking on outgroup prosocial behaviour was not significant $(b=-.05$, se $=.04, p>.05)$, suggesting full mediation.

\section{Discussion}

The current study aimed to explore the role of essentialist beliefs about ethnoreligious categories on the outgroup-directed empathy, attitudes, and prosocial behaviours of children living post-accord Northern Ireland. The findings suggest that essentialist beliefs may influence children's engagement in intergroup behaviours relating to peacebuilding in settings of intergroup conflict. Children with lower essentialist beliefs assumed 'Protestant' and 'Catholic' categories were less physically and psychologically distinct. By assuming more flexible boundaries and similarities between "us" and "them," children with lower essentialist beliefs about ethno-religious categories tended to have greater outgroup empathy, which predicted more positive attitudes and in turn, prosocial behaviours across group lines. These findings replicate and build on the empathy-attitudes-action model (Taylor et al., 2020a). Holding lower essentialist beliefs may contribute to the unfreezing of traditional conflict dynamics by fostering more constructive intergroup behaviours, which may provide a foundation for future collaboration and consolidation of peace (Taylor et al., 2014). 
The finding that essentialist beliefs influence children's prosocial behaviours is consistent with previous work. For example, essentialism related to sharing fewer resources with an outgroup member but did not promote more negative outgroup attitudes in a minimal group paradigm (Rhodes et al., 2017). Given the socially salient groups involved in the current study, however, it is likely that outgroup attitudes may also be important in the link between essentialist beliefs and children's intergroup behaviours.

There was, however, considerable variability in children's essentialist beliefs. Multiple factors may contribute to some children having more essentialist beliefs than others. That is, essentialist beliefs may increase when social categories are highly salient (Diesendruck, Goldfein-Elbaz, Rhodes, Gelman, \& Neumark, 2013) or labelled with generic nouns (Rhodes, Leslie, \& Tworek, 2012). For example, children may live in neighbourhoods that experience ongoing sectarian violence or in families that transmit conflict-related language conducive to the development of essentialist beliefs (Taylor et al., 2020b).

In this study, older children reported more negative perceptions of the other community on the outgroup attitudes measure. This finding could be linked to living in social environments characterised by intergroup conflict and division, which may catalyse the development of negative outgroup attitudes.

The findings of the study should be considered in the light of limitations, which could be addressed in future research. First, given that the study adopted a cross-sectional, correlational design it is not possible to make inferences on causation or the direction of effects. Other directions may be possible. For example, essentialist beliefs about ethnoreligious categories may have arisen as a justification for lacking empathy for the other community. Future research should adopt longitudinal designs to unravel the directionality of effects. Second, the study had a small sample size, which may limit the generalisability of findings. Other correlations within the model may be significant, however, these are not 
detectable due to insufficient statistical power. Similarly, the sample does not allow for examination of nested factors in schools or classrooms, which may influence variables in the model. It would be beneficial for future research to replicate these findings using larger samples and conduct multi-level analysis for nested data. Third, although age was only a significant predictor of outgroup attitudes in this study, future research should investigate age-based changes in the other variables as children transition into adolescence and acquire increased understanding of group dynamics and consolidate identities. Finally, short scales were used in an effort to be child-friendly and accessible across varying comprehension levels. Although commensurate with previous developmental research, some measures displayed low internal consistencies (e.g., outgroup-directed empathy). Future research should utilise more comprehensive measures of these constructs.

The study adds to our understanding of children's systems of cognitions, emotions, attitudes, and behaviours amid entrenched intergroup divisions. By linking essentialist beliefs to children's outgroup-directed empathy, attitudes, and behaviours within a real-world context, the study makes a valuable and unique contribution to the literature. The findings also have important implications for peacebuilding practitioners, highlighting the need for interventions to reduce children's essentialist beliefs around social categories to foster positive intergroup attitudes and behaviours. For example, interventions could emphasise shared properties that exist between groups to help children to recognise that characterises of group members exist on a spectrum instead of being all-or-nothing. Similarly, the use of nongeneric language at home and school may be effective in dampening the intergenerational transmission of essentialist beliefs. Such interventions may foster positive future intergroup relations within Northern Ireland and other conflict-affected societies.

\section{Ethical Compliance Statement}


The study was supported financially by the School of Psychology Research Incentivisation Scheme and Summer Student Scheme at Queen's University Belfast. Ethical approval was secured from Queen's University Belfast. The procedure of this study was carried out in accordance with the 1964 Helsinki Declaration and later amendments. The authors declare that they have no conflict of interest. Children received a certificate and a small prize for taking part. Primary schools also received a $£ 75$ Amazon voucher. Informed consent was obtained from school principals, parents and children before participating in the study. 


\section{ESSENTIALISM AND INTERGROUP RELATIONS}

\section{References}

Cohen, J. (1992). A power primer. Psychological Bulletin, 112(1), 155-159. https://doi.org/10.1037/0033-2909.112.1.155

Dautel, J.B. (2012). The cost of conflict: Children's reasoning about ethno-religious identity in Northern Ireland. Perspectives on Europe, 42, 74-78.

Diesendruck, G., Goldfein-Elbaz, R., Rhodes, M., Gelman, S., \& Neumark, N. (2013). Crosscultural differences in children's beliefs about the objectivity of social categories. Child Development, 84(6), 1906-1917. https://doi.org/10.1111/cdev.12108

Diesendruck, G., \& Haber, L. (2009). God's categories: The effect of religiosity on children's teleological and essentialist beliefs about categories. Cognition, 110(1), 100-114. https://doi.org/10.1016/j.cognition.2008.11.001

Diesendruck, G., \& Menahem, R. (2015). Essentialism promotes children's inter-ethnic bias. Frontiers in Psychology, 6, 1180. https://doi.org/10.3389/fpsyg.2015.01180

Diesendruck, G., \& Weiss, E. (2015). Children's differential weighting of cues to social categories. Cognitive Development, 33, 56-72. https://doi.org/10.1016/j.cogdev.2014.06.001

Gelman, S.A. (2003). The essential child: Origins of essentialism in everyday thought. New York: Oxford University Press. https://doi.org/10.1093/acprof:oso/9780195154061.001.0001

Masten, C.L., Gillen-O’Neel, C., \& Brown, C.S. (2010). Children's intergroup empathic processing: The roles of novel ingroup identification, situational distress, and social anxiety. Journal of Experimental Child Psychology, 106(2), 115-128. https://doi.org/10.1016/j.jecp.2010.01.002 
Nesdale, D., Milliner, E., Duffy, A., \& Griffiths, J.A. (2009). Group membership, group norms, empathy, and young children's intentions to aggress. Aggressive Behavior, 35(3), 244-258. https://doi.org/10.1002/ab.20303

O’Driscoll, D., Taylor, L.K., \& Dautel, J.B. (2018). Intergroup resource distribution among children living in segregated neighborhoods amid protracted conflict. Peace and Conflict: Journal of Peace Psychology, 24(4), 464-474. https://doi.org/10.1037/pac0000348

Reidy, C.M., Taylor, L.K., Merrilees, C.E., Ajdukovíc, D., Čorkalo Biruški, D., \& Cummings, E.M. (2015). The political socialization of youth in a post-conflict community. International Journal of Intercultural Relations, 45, 11-23. https://doi.org/10.1016/j.ijintrel.2014.12.005

Rhodes, M., Leslie, S.J., Saunders, K., Dunham, Y., \& Cimpian, A. (2017). How does social essentialism affect the development of inter-group relations? Developmental Science, 21(1), 1-15. https://doi.org/10.1111/desc.12509

Rhodes, M., Leslie, S.J., \& Tworek, C.M. (2012). Cultural transmission of social essentialism. Proceedings of the National Academy of Sciences, 109(34), 1352613531. https://doi.org/10.1073/pnas.1208951109

Smyth, K., Feeney, A., Eidson, R.C., \& Coley, J.D. (2017). Development of essentialist thinking about religion categories in Northern Ireland (and the United States). Developmental Psychology, 53(3), 475-496. https://doi.org/10.1037/dev0000253

Taylor, L.K., \& McKeown, S. (2017). Youths' peacebuilding potential: Intergroup contact and civic participation amongst a post-accord generation in Northern Ireland. In K. Niven, S. Lewis, \& C. Kagan (Eds.), Making a difference with psychology (pp. 5662). London, UK: Richard Benjamin Trust. 
Taylor, L.K., Merrilees, C.E., Goeke-Morey, M.C., Shirlow, P., Cairns, E., \& Cummings, E.M. (2014). Political violence and adolescent outgroup attitudes and prosocial behaviors: Implications for positive intergroup relations. Social Development, 23(4), 840-859. https://doi.org/10.1111/sode.12074

Taylor, L.K., O’Driscoll, D., Dautel, J.B., \& McKeown, S. (2020a). Empathy to action: Child and adolescent outgroup attitudes and prosocial behaviours in a setting of intergroup conflict. Social Development. https://doi.org/10.1111/sode.12421

Taylor, L.K., Štambuk, M., Čorkalo Biruški, D., \& O’Driscoll, D. (2020b). Transgenerational transmission of collective victimhood through a developmental intergroup framework: The lasting power of group narratives of suffering. In J. Vollhardt (Ed.), The Social Psychology of Collective Victimhood. Oxford, UK: Oxford University Press.

Turner, R.N., Tam, T., Hewstone, M., Kenworthy, J., \& Cairns, E. (2013). Contact between Catholic and Protestant schoolchildren in Northern Ireland. Journal of Applied Social Psychology, 43, 216-228. https://doi.org/10.1111/jasp.12018 
Table 1: Means, standard deviations, and bivariate correlations of study variables $(\mathrm{N}=88)$.

\begin{tabular}{|c|c|c|c|c|c|c|c|c|c|c|}
\hline Variables & $M$ & $S D$ & $\alpha$ & Range & 1 & 2 & 3 & 4 & 5 & 6 \\
\hline 1 Female & & $47.7 \%$ female, $52.3 \%$ male & & & - & & & & & \\
\hline 2 Catholic & & $50.0 \%$ Catholic, $50.0 \%$ Protestant & & & .00 & - & & & & \\
\hline 3 Age & 7.09 & 1.47 & & & -.04 & -.08 & - & & & \\
\hline 4 Essentialist beliefs & .11 & 4.56 & .65 & $\begin{array}{l}0-24 \text { (distinctiveness) } \\
0-6(\text { stability })^{2}\end{array}$ & $-.26^{*}$ & -.17 & -.14 & - & & \\
\hline $\begin{array}{l}5 \text { Outgroup-directed } \\
\text { empathy }\end{array}$ & 7.81 & 2.52 & .48 & $0-12$ & .10 & .00 & -.03 & $-.31 * *$ & - & \\
\hline 6 Outgroup attitudes & 8.35 & 2.70 & .84 & $0-9$ & .02 & -.01 & -.18 & .16 & $.31 * *$ & - \\
\hline 7 Outgroup prosocial & 3.01 & 1.48 & $\mathrm{NA}^{1}$ & $0-7$ & -.07 & .01 & -.11 & -.11 & -.05 & $.29 * *$ \\
\hline
\end{tabular}

${ }^{1}$ No internal consistency was calculated as the total number of stickers shared was a frequency variable.

${ }^{2} \mathrm{z}$-scores were used to combine subscales.

Note: $* p<.05, * * p<.01, * * * p<.001$. 
Figure 1. Bootstrapped chain mediation for the effect of children's essentialist beliefs about ethno-religious categories on outgroup-directed empathy, attitudes, and prosocial behaviour $(\mathrm{N}=88)$. Control variables of age, sex, and community background have been removed to improve readability. Unstandardized regression coefficients are reported with $95 \%$ confidence intervals included in parenthesis. Note: $* p<.05, * * p<.01, * * * p<.001$.

-.01 (CI: $-.029,-.001)$

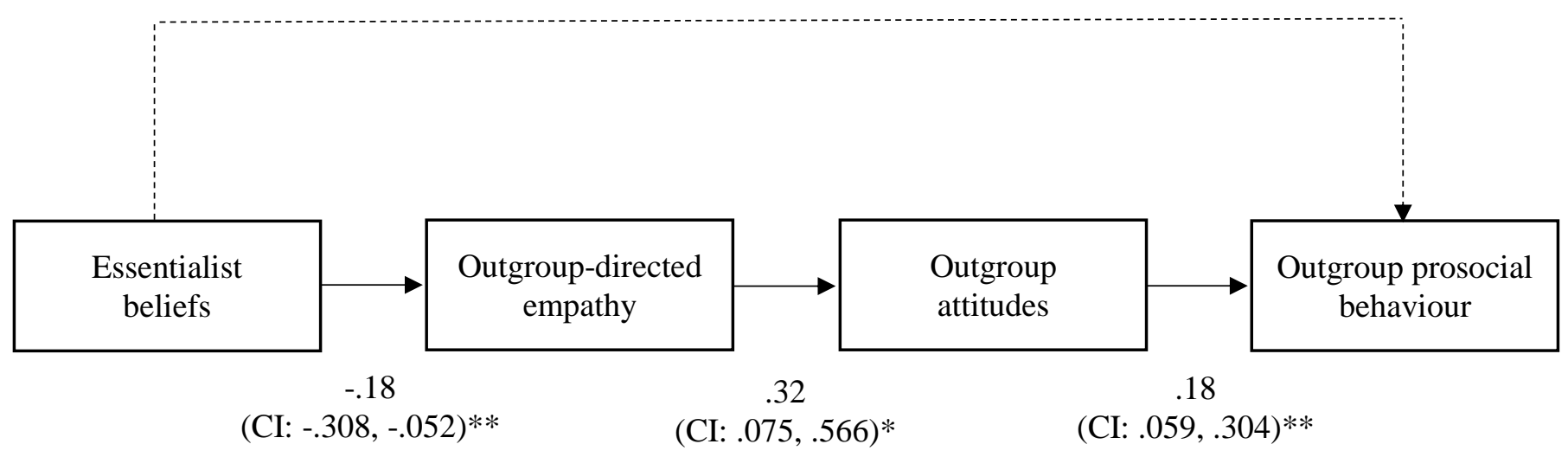

